\title{
Impacts of a single fire event on large, old trees in a grass-invaded arid river system
}

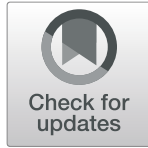

Christine A. Schlesinger ${ }^{*}$ (iD and Erin L. Westerhuis

\begin{abstract}
Background: Large old trees are keystone structures of terrestrial ecosystems that provide unique habitat resources for wildlife. Their widespread decline worldwide has serious implications for biodiversity and ecosystem integrity. In arid regions, large trees are relatively uncommon and often restricted to areas with elevated soil moisture and nutrients. Introduced grasses, now pervasive in many dryland environments, also thrive in such areas and are promoting more frequent and intense fire, potentially threatening the persistence of large trees. Here we report on the impact of a single wildfire on large river red gums (Eucalyptus camaldulensis Dehnh.) in arid riparian woodland invaded by buffel grass (Cenchrus ciliaris L.), a serious invader of desert ecosystems worldwide. In 2018, 266 trees with $>80 \mathrm{~cm}$ equivalent trunk diameter were mapped at six sites to provide a 'pre-fire' baseline. Within a year, the sites were impacted by a large, unprecedented wildfire that burnt an area of $660 \mathrm{~km}^{2}$ ha in 15 days. Sites were resurveyed in February 2019 to assess the fate of the trees. Reference to fire severity, calculated from remote-sensed imagery, is provided for additional context.

Results: In total, 67 trees, $27 \%$ of all large trees at the sites were destroyed. If trees in unburnt patches are excluded, 54\% of trees exposed to the fire were destroyed and the remainder lost on average $79 \%$ of their canopy.

Conclusions: This severe detrimental effect of a single fire, on trees estimated to be centuries old, is indicative of tree-loss occurring across remote arid Australia in habitats where fire is now fuelled predominantly by invasive grasses. Large volumes of novel grass fuels along creeklines in combination with extreme weather events were major factors driving the spread, extent and impacts of the wildfire we report on and are causing a shift from relatively uncommon and predictable, rainfall-dependent large wildfires to large, severe fires that can occur anytime. We predict further decline in the abundance of large trees from similar fires will occur widely throughout arid Australia over the next decade with substantial long-term impacts on multiple species. New strategies are urgently required to manage fire in invaded arid ecosystems to better protect large trees and the critical resources they provide.
\end{abstract}

Keywords: Invasive alien grasses, Disturbances, Cenchrus ciliaris, Wildfire, Large trees, Arid riparian woodland, Eucalyptus camaldulensis, Australia

\footnotetext{
* Correspondence: christine.schlesinger@cdu.edu.au

Research Institute for the Environment and Livelihoods, Charles Darwin University, Alice Springs Campus, Grevillia Drive, Alice Springs, NT 0870, Australia
} 


\section{Resumen}

Antecedentes: Los árboles grandes y añosos son estructuras claves de los ecosistemas terrestres ya que proveen recursos y hábitat para la vida silvestre. Su extendida declinación a nivel mundial tiene serias implicancias para la biodiversidad y la integridad de los ecosistemas. En regiones áridas, los árboles grandes son poco comunes y frecuentemente restringidos a áreas con elevada humedad del suelo y nutrientes. Los pastos introducidos, ahora generalizados en muchos sistemas de secano, también prosperan en esas áreas, y promueven fuegos más intensos y frecuentes, amenazando la persistencia de agrandes árboles. Reportamos acá el impacto de un incendio sobre rodales de eucaliptus rojo (Eucalyptus camaldulensis Dehnh.) ubicados a la vera de un largo río cuyas riveras estaban invadidas por pasto búfalo (Cenchrus ciliaris L.), un serio pasto invasor en ecosistemas de desierto en todo el mundo. En 2018, 266 árboles con un diámetro equivalente $>80 \mathrm{~cm}$ fueron mapeados en seis lugares para proveer una línea de base pre-fuego. Durante ese año, los sitios fueron impactados por un gran incendio que no había tenido precedentes y que quemó $660 \mathrm{~km}^{2}$ en 15 días. Los sitios fueron relevados en febrero de 2019 para determinar el destino de los árboles. La referencia sobre la severidad del fuego, calculada mediante imágenes de sensores remotos, fue provista como un contexto adicional.

Resultados: En total, 67 árboles, el 27\% de todos los árboles grandes de estos sitios fueron totalmente destruidos por el fuego. Excluyendo del análisis los árboles en los parches no quemados, el 54\% de los árboles expuestos al fuego fueron destruidos y del resto, un 79\% promedio perdieron sus doseles.

Conclusiones: Este efecto perjudicial de un fuego individual en árboles que estimativamente tienen cientos de años, es indicativo de las pérdidas árboles ocurridas a lo largo de áreas remotas de las zonas áridas de Australia, donde ahora el fuego es estimulado predominantemente por pastos invasores. Un gran volumen de pastos nuevos y combustibles a la vera de arroyos, en combinación con eventos meteorológicos extremos, fueron los mayores factores conducentes a la propagación, extensión, e impactos que reportamos, y están causando un desvío de grandes incendios relativamente poco frecuentes y predecibles, dependientes de la lluvia, a incendios grandes y severos que pueden ocurrir en cualquier momento. Podemos predecir que, en la próxima década, en lugares áridos de toda Australia habrá una mayor declinación en la abundancia de grandes árboles debido a fuegos similares al reportado, con impactos a largo plazo en múltiples especies. Nuevas estrategias son urgentemente requeridas para manejar el fuego en ecosistemas áridos invadidos para proteger los árboles grandes y añosos, y los recursos críticos que ellos proveen.

\section{Introduction}

Large old trees are keystone habitat features in ecosystems world-wide, with importance for wildlife. They provide unique and diverse microclimates, foraging substrates, and nesting sites (Dean et al. 1999; Haworth and McPherson 1995; Law et al. 2016; Lumsden et al. 2002a; Whelan and Maina 2005). Of particular value are the hollows and cavities of a variety of shapes and sizes that typically occur on large trees, some of which can take decades or even centuries to develop (Haslem et al. 2012; Parnaby et al. 2011). These attributes are important to diverse groups of fauna including birds (Aumann 2001; Dean et al. 1999; Goldingay 2009), bats (Clews 2016; Lumsden et al. 2002b; Rhodes and WardellJohnson 2006; Goldingay 2009), mammals (Dickman 1991; Goldingay 2011), reptiles (McElhinny et al. 2006) and invertebrates (Majer et al. 1997). Large old trees are, however, declining in many parts of the world (Lindenmayer et al. 2012). Given the high habitat value of large trees and the length of time they take to grow, the loss of even a single tree can have significant and longlasting consequences for local biodiversity, especially where few such trees remain (Lindenmayer and Laurance 2016). While land clearing for forestry and agriculture continues to threaten the persistence of large old trees in many regions, fire has increasingly become another major risk (Lindenmayer and Laurance 2016), particularly as current climatic patterns are supporting unprecedented severe fire events (Nolan et al. 2020) even in ecosystems with minimal recent history of fire (Marris 2016).

\section{Distribution of large trees in arid Australia and the threat from fire fuelled by invasive grasses}

In the Australian arid zone, large trees are naturally scarce and completely absent in some regions. The highest densities occur in open woodlands associated with drainage lines and flood-outs. Although the inland creeks of central Australia are ephemeral, and flow only for short periods following rain, permanent sub-surface water is accessible to deep-rooted trees growing along the creek beds, banks and adjacent floodplains (Reid 2015). The persistence of large trees in these arid riverine woodlands is, however, increasingly threatened by 
introduced grasses that significantly alter fire regimes, especially buffel grass (Cenchrus ciliaris L. = Pennisetum ciliare L.). A high biomass and drought-tolerant grass, buffel grass has invaded diverse habitats in dryland Australia but is especially pervasive along creek lines and adjacent lowland plains (Duguid et al. 2008; Friedel et al. 2014; Schlesinger et al. 2013; Fig. 1).

Increased frequency, intensity and extent of fire promoted by introduced grasses is one of the most serious contemporary threats to biodiversity in arid ecosystems (D'Antonio and Vitousek 1992), and buffel grass, a
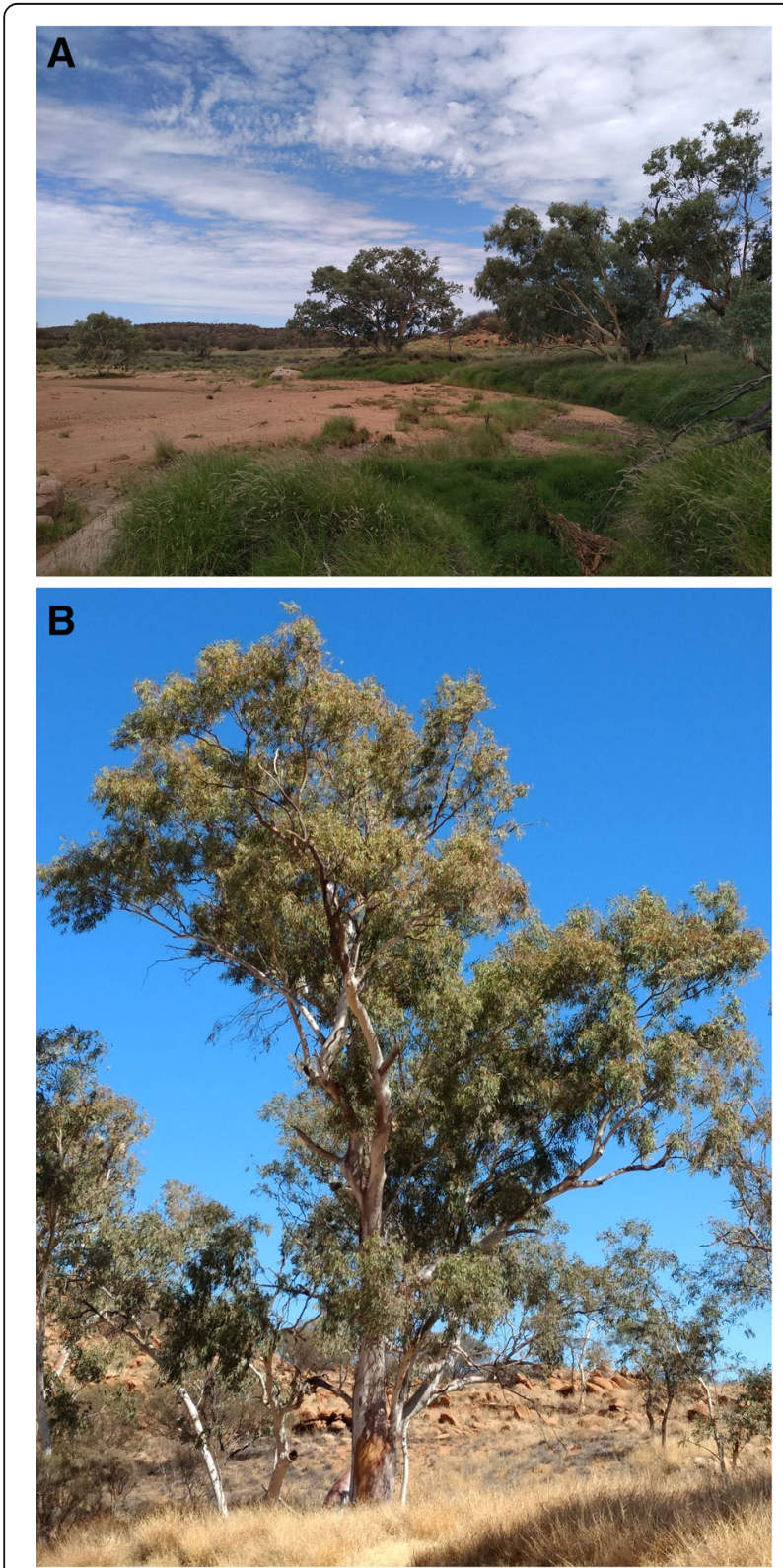

Fig. 1 a Large river red gums amid a dense monoculture of buffel grass on the banks of a sandy creek line following recent rain and $\mathbf{b}$ during more frequent dry conditions (photos, Christine Schlesinger) perennial native of south and east Africa and southern Asia, is one of the worst of the fire-promoting invaders (Godfree et al. 2017; Grice 2006; McDonald and McPherson 2013; van Klinken and Friedel 2017). In Australia, buffel grass has been ranked with the most serious environmental threats for projected future impacts on dryland biodiversity (Read et al. 2020) although it is less well-recognised and has received much less research attention compared to other threats. In buffelinvaded arid regions worldwide, there has been increasing concern expressed about the impacts of buffelfuelled fire, particularly on large trees and other longlived keystone plants (Abella et al. 2012; Clarke et al. 2005; McDonald and McPherson 2011; Schlesinger et al. 2013; Rodríguez-Rodríguez et al. 2017).

The river red gum (Eucalyptus camaldulensis subsp. arida Brooker \& M.W. McDonald), although restricted to the banks and floodplains of creeks, is the most widespread arid-zone tree species in Australia. It has special significance, therefore, with respect to the provision of wildlife habitat. The largest individual trees are especially important for cavity dependent fauna because they have the most hollows (Westerhuis et al. 2019). River red gums are susceptible to cambial injury when exposed to fire or other disturbance, which predisposes the tree to fungal and insect attack, and thereby promotes hollow development (Gibbons et al. 2010), although it can take decades to produce hollows suitable for occupation by fauna through these processes. Because hollow trees are also more susceptible to subsequent fire, the development of large old trees with numerous hollows is only supported in a system when fire intensity and frequency are relatively low (Haslem et al. 2012). In recent decades, in those regions where buffel grass has invaded, increasing exposure to frequent and severe fire appears to be threatening the persistence of large hollow bearing river red gums. Across Australia, the species is already estimated to have declined by $29 \%$ since European settlement and is listed as Near Threatened (Fensham et al. 2019). The threat caused by interactions between invasive grasses and fire on the arid subspecies is, therefore, of particular concern.

\section{Research aims}

Although increasingly referenced, especially in the grey literature (e.g. Day 2020), to date there have been a lack of published empirical data documenting the extent of damage to river red gums from fire fuelled by invasive grasses. We aimed to contribute to filling this gap. In June 2018, baseline data on the location of large river red gums were collected along a heavily invaded ephemeral creek that had been minimally impacted by fire since buffel grass had become dominant. 
A large wildfire occurred in the region approximately 6 months later, and here, we report on the impact of this fire on the mapped trees. Fire severity, calculated from remotely sensed imagery, is provided to assist with interpretation and the conditions under which the fire occurred and spread are discussed. Conclusions are drawn with respect to future fire patterns and the persistence of large old trees in riparian woodlands invaded by buffel grass in arid Australia.

\section{Methods}

\section{Study area and site characteristics}

The MacDonnell Ranges form part of a mountainous region in central Australia with complex topography, including tall ranges, rocky hills and extensive lowland plains, and are the source of several major inland rivers. Throughout the region, the creekbanks, floodplains and other lowland areas are heavily invaded by buffel grass. The other commonly present introduced grass is couch grass (Cynodon dactylon L.) which has a more restricted distribution along some creekbanks. These high biomass grasses commonly form dense swards and have substantially replaced what was a comparatively sparse native understory of mixed grasses, chenopods and other forbs (Clarke et al. 2005). The overstorey in the lowland areas includes river red gum woodlands (near the creeklines) and mixed open woodland or shrubland elsewhere (incl. Corymbia aparrerinja K.D.Hill \& L.A.S.Johnston, C.opaca (D.J.Carr \& S.G.M.Carr) K.D.Hill \& L.A.S.Johnson, Grevillea striata R.Br. Hakea sp., Acacia estrophiolata F.Muell, and A. victoreae Benth.). Other major plant communities in the MacDonnell ranges bioregion are Acacia shrublands (dominated by Acacia aneura F.Muell. ex Benth. and Acacia kempeana F.Muell.) which often occur on the lower slopes, and native spinifex (Triodia sp.) hummock grasslands that dominate the steeper rocky hillslopes and often co-occur with a sparse overstorey of Eucalypts, especially mallee-form species. Buffel grass has been slower to invade the Acacia shrublands and spinifex grasslands, and although this is changing in some areas, many of these upland plant communities still feature a predominantly native understory.

Our survey area was approximately $150 \mathrm{~km}$ from the town of Alice Springs (latitude -23.655, longitude 132.729) within the Tjoritja / West MacDonnell Ranges National Park (hereafter-Tjoritja). The park extends for $161 \mathrm{~km}$ westward from Alice Springs, incorporating many of the tallest ranges and sheltered gorges within the bioregion; covers an area of $2568 \mathrm{~km}^{2}$; and is recognised internationally for its natural environment and as a place of cultural importance (Day 2020). Before Tjoritja was established, the area was used extensively for cattle grazing but domestic stock have been excluded for approximately $30-50$ years as different areas became incorporated into the park. The six survey sites were originally established in 2016 along a
$5.5 \mathrm{~km}$ section of Ormiston Creek, a tributary of the Finke River, as part of ongoing research on the local avifauna. Each site measured $500 \mathrm{~m}$ along the creek (Fig. 2) and included trees in the creek bed and on the banks. The buffelinvaded creekbanks and floodplains (which were of variable width) were bordered by predominantly buffel-free rocky hillslopes which retained a native understory dominated by spinifex grasses. At three sites $(1,3,5)$, river red gums grew only along the banks with few or no trees or shrubs in the creek bed ('simple' sites). The other three sites $(2,4,6)$ had river red gums and shrubs (predominantly inland tea treeMelaleuca glomerata F.Muell.) lining the banks and growing on sand islands between parallel smaller channels, and sometimes in the creek bed ('complex' sites).

Ground cover along the banks of all sites was dominated by buffel grass with discontinuous patches of couch grass also occurring in some areas. Cover in the creek was much more variable with some of the vegetated sand islands of complex sites heavily invaded, while others had no introduced grasses present. The creek bed was either sandy or rocky and tended to have very low ground cover, and no buffel or couch grass present. Based on estimates made when the sites were first established, ground cover within a 5-m radius under a

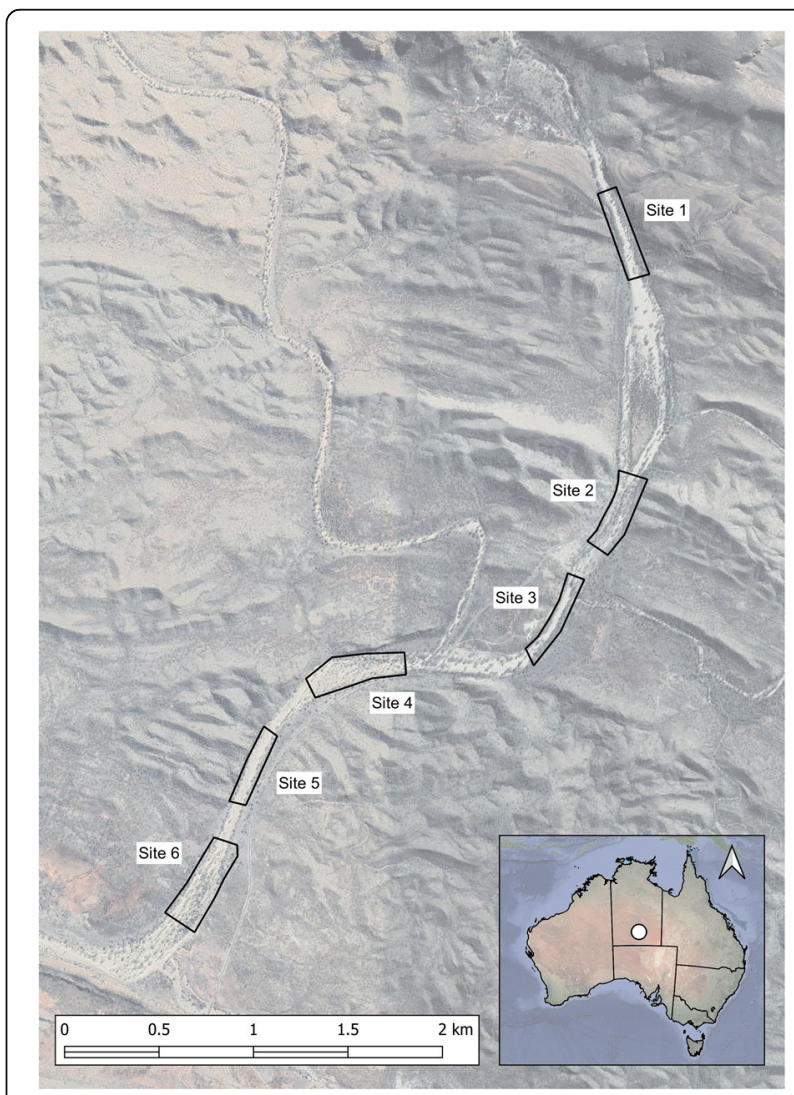

Fig. 2 Location of the six sites along Ormiston Creek. Inset shows the location of the area within the Northern Territory, Australia 
random sample of river red gums averaged 56\% $( \pm 27)$ beneath trees on the bank ( $n=310$, across six sites) and $21 \%( \pm 23)$ in the creek bed and sand islands of complex sites ( $n=149$, across three sites) and average modal height was $66( \pm 29) \mathrm{cm}$ on the banks and $59( \pm 29)$ in the creek bed. We did not measure fuel loads; however, it has been previously documented that buffel grass invasion is associated with at least a doubling or tripling of fuel loads in central Australian open woodland communities. Miller et al. (2010) recorded $1804 \pm 154$ (SE) kg $\mathrm{ha}^{-1}$ above-ground biomass at buffel-free sites compared to $6679 \pm 969$ (SE) $\mathrm{kg} \mathrm{ha}^{-1}$ at sites where buffel grass was non-continuous and invasion was ongoing. Fuel loads on the banks at our study sites where buffel grass was long established and had achieved near-continuous dense cover were likely considerably higher.

\section{Assessment of large old trees}

River red gums were visually assessed from the ground in June 2018. All trees not obviously too small were measured to check their size against the thresholds that we used to define large trees: trunks $\geq 80 \mathrm{~cm} \mathrm{DBH}$ (diameter at breast height) for single-stemmed trees, and at least one stem $\geq$ $50 \mathrm{~cm} \mathrm{DBH}$ for multi-stemmed trees. Trees with trunks at or above these diameters have basal areas greater than $0.4 \mathrm{~m}^{2}$ and characteristically have multiple hollows present (Westerhuis et al. 2019). The locations of 266 large river red gums (excluding stumps)-all those detected that met the criteria-were recorded with a handheld GPS.

On 12 January 2019, a fire was ignited by lightning at a site $65 \mathrm{~km}$ to the east of Ormiston Creek and burnt generally westward covering an area of $660 \mathrm{~km}^{2}$ (approximately $22 \%$ of the park area, including our survey area) over 2 weeks (Day 2020). Approximately a month after the wildfire, in February 2019, we attempted to find all the mapped trees again. Once found, trees were categorised as follows: A. unaffected-no evidence of fire impact to main tree structure or canopy, or no evidence the fire reached the area where the tree was located; B. affected-clear evidence of scorching on the trunk, or canopy partially or completely scorched or burnt; and C. destroyed-main stem of tree reduced to a stump or tree completely incinerated and evident only as ash and a hole in the ground (see Fig. 3 for examples of each category). Although some

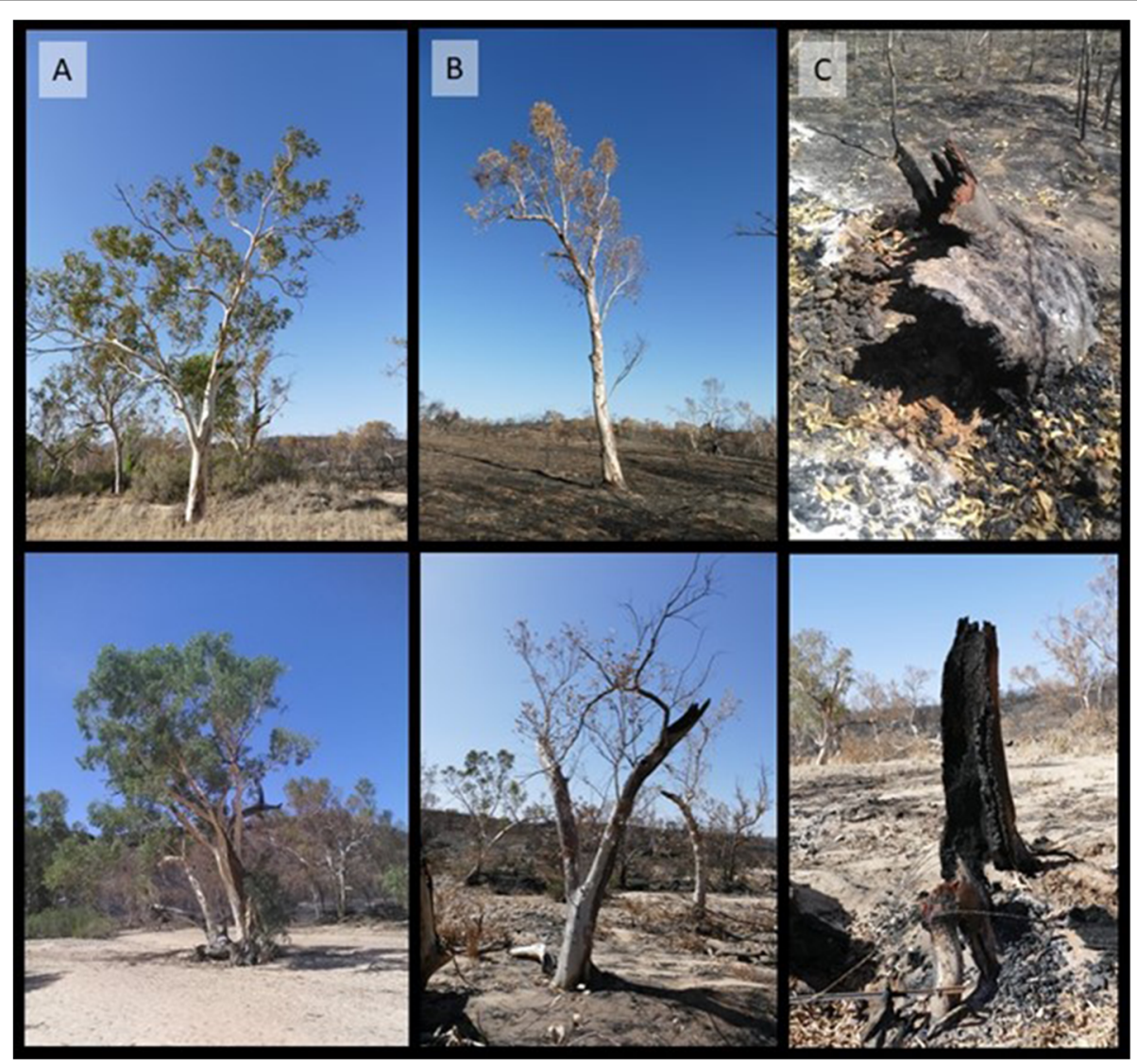

Fig. 3 Example of post-fire tree types. A Unaffected trees on unburnt bank (top) and in creek bed (bottom). B Affected trees with partial canopy scorch (top) and full canopy scorch (bottom). C Destroyed trees, completely combusted (top) and stump remaining (bottom) (photos, Erin Westerhuis) 
of the trees reduced to stumps are likely to resprout in the future, we considered their value as large trees to have been permanently lost (if current fire-regimes persist) or, otherwise, lost for over a century. For trees that were affected but not destroyed, we also visually estimated the extent of scorching of the canopy (i.e. leaves consumed or still in place, but dead) to the nearest $10 \%$, and the maximum height at which scorching was apparent.

\section{Assessment of fire severity}

Fire severity at the sites and surrounding region was assessed using the delta normalised burn ratio ( $\triangle$ NBR) calculation on pre- and post-fire Sentinel-2 images of the study area (Zone/ Path 53KKP). To minimise differences between images relative to moisture and plant phenology (Lutes et al. 2006), images from 15 December 2018 and 28 February 2019 (those closest to before and after the fire) were used. Buffel grass in Tjoritja was fully cured by extreme heat in December and January (Day 2020) and only $10 \mathrm{~mm}$ of rainfall was recorded at Ormiston Gorge ( $<1 \mathrm{~km}$ from site 1, Bureau of Meteorology 2021) between the dates when the images were recorded. Any herbaceous plant growth during this interval was therefore assumed to be insignificant. Images were downloaded and converted to at-surfacereflectance using the SCP plugin (Congedo 2016) in QGIS version 3.16.0.

The delta NBR was calculated as:

$$
\Delta \mathrm{NBR}=\mathrm{NBR}_{\text {pre fire }}-\mathrm{NBR}_{\text {post fire }},
$$

where NBR $=$ (band $8-$ band 12) / (band $8+$ band 12).

This uses the Sentinel-2 bands which respond strongly, but in opposite ways, to changes to the landscape following a fire. Band 8 of Sentinel-2 images acquires wavelengths in the near-infrared spectrum $(0.785-0.900 \mu \mathrm{m})$ and is responsive to biomass, while band 12 acquires far short-wave infrared reflectance $(2.100-2.280 \mu \mathrm{m})$ and is responsive to the moisture content of soil and vegetation. The difference between the two bands for each image is normalised by the sum of the two bands. This removes some of the effects of topography and differences in solar illumination between dates. The accuracy of the delta NBR was checked against high temporalresolution hotspots recorded in the area between 12 and 27 January 2019 using the Northern Australian Fire Information (NAFI) plugin (Lynch 2020) for QGIS version 3.16.0. Finally, the delta NBR was used to generate a polygon of the fire scar at the sites and in the surrounding areas using tools in QGIS.

To compare remotely sensed and ground-based measures, the delta NBR values for a $30 \times 30 \mathrm{~m}^{2}$ surrounding each tree ( 9 pixels) were extracted. The use of nine pixels provided a less precise but more accurate indication of the fire severity trees were exposed to by allowing for variability in the accuracy of GPS coordinates of trees. The average delta NBR value was calculated for the 9 pixels surrounding each tree point and the mean delta NBR value and quartile ranges were calculated for each post-fire tree category.

\section{Results}

Of 256 trees re-identified after the fire, 67 (27\%) were destroyed, 98 (40\%) were affected but not destroyed and 81 (33\%) were unaffected by the fire. Ten other trees, mapped prior to the fire, could not be found, possibly due to inaccuracies in their GPS coordinates. Unaffected trees were, predictably, associated with low delta NBR values $(<50)$ (Fig. 4) and were mostly growing within a few larger patches where the fire did not reach, including the entire western bank of site 2 and part of the western bank of site 3 (Fig. 5). Others were growing within the creek bed at sites 2, 4, and 6. Destroyed and affected trees were, conversely, in areas with higher delta NBR values with destroyed trees tending to be associated with the highest delta NBRs (Fig. 4).

There were some exceptions, however, where trees were destroyed or affected in areas where the fire severity index was relatively low. This was especially evident at site 6 , where some trees within the creek bed were destroyed, and many others were affected despite overall fire severity being much lower compared to the banks (Fig. 5). Ground-based observations post-fire confirmed that some of these trees were surrounded by bare sand and that the fire had spread directly from canopy to canopy, even when the nearest tree was tens of metres away, an indication of the intensity of the fire at this site. Excluding site 6 , almost all the destroyed trees were on the banks which were dominated by buffel grass. Of the 156 trees that the fire reached, 54\% were destroyed and those remaining had an average of $78.7 \%( \pm 20.93 \mathrm{SD})$ of their canopy burnt with fire damage evident on average up to $11.0 \mathrm{~m}$ high ( $\pm 3.0 \mathrm{SD})$. Approximately a third of the affected but not destroyed trees lost 100\% of their canopy.

\section{Discussion}

\section{Impacts of fire on large trees and wildlife habitat}

The severe detrimental effect of the 2019 fire at Tjoritja, here documented, on trees estimated to be centuries old, is indicative of tree-loss occurring across remote arid Australia in habitats where fire is now fuelled predominantly by invasive grasses. The 2019 fire, to our knowledge, is only the second to affect the section of Ormiston Creek where our sites were situated since buffel grass began to dominate riparian woodlands in the West MacDonnell Ranges in the 1990s. This is likely because this portion of the creek is in a relatively isolated valley which has been afforded some degree of 


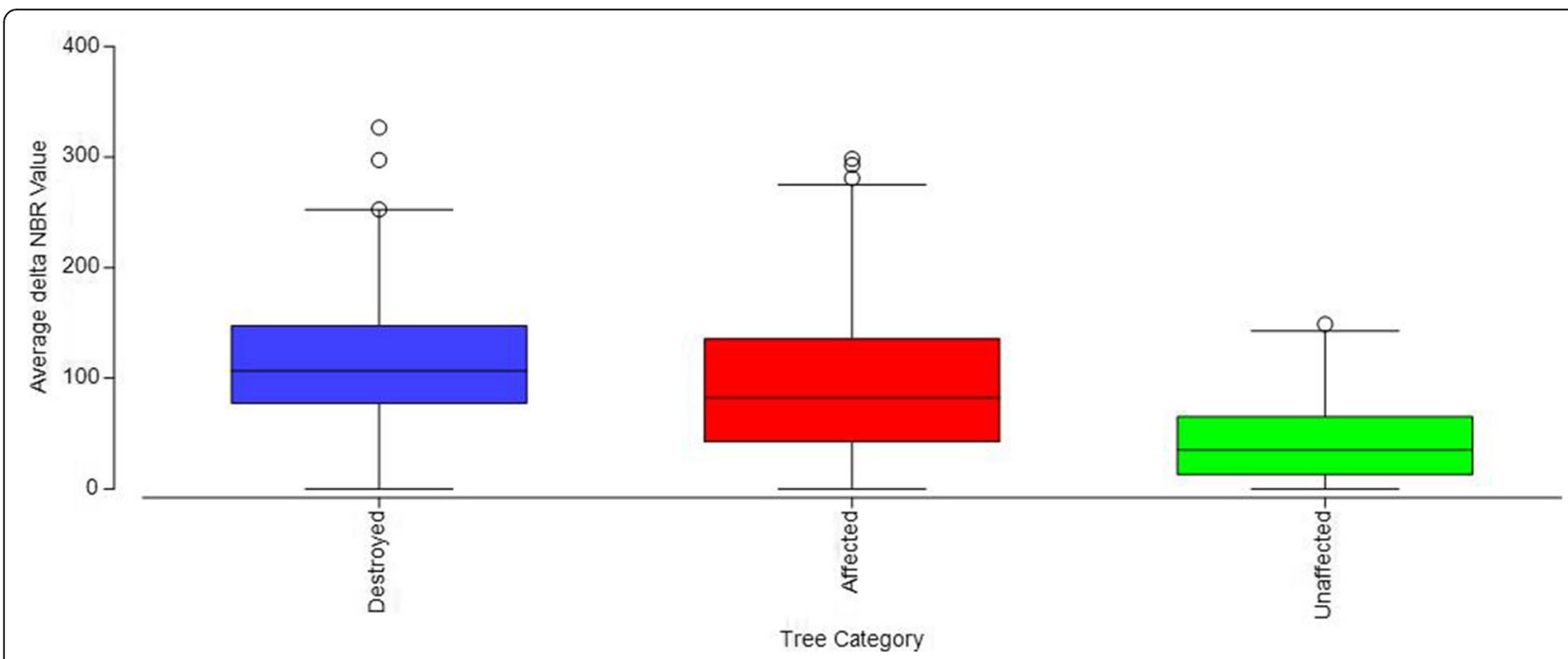

Fig. 4 Box plot of average delta NBR values for destroyed, affected and unaffected river red gums calculated from nine pixels closest to the tree location (equivalent to $30 \times 30 \mathrm{~m}^{2}$ )

protection from management of fuel loads in the surrounding spinifex dominated rocky hills. The area was burnt in 2001 but there are no definitive records of the extent to which buffel grass contributed to fuel loads at that time. The creek area was used for pastoralism until 1992 when it was incorporated into the National Park (Gary Weir pers. comm.) and anecdotal reports suggest it took years before all the cattle were removed, and that ongoing grazing may have slowed the accumulation of high fuel loads. When our monitoring sites were established in 2016, the trees appeared to be relatively intact, with no evidence of recent fire damage. This contrasted with many of the other rivers and creeks in Tjoritja, situated in less protected areas, where multiple fires have occurred since buffel grass became dominant. Our results for Ormiston Creek, therefore, provide unique insights into the ongoing impacts of fire, anecdotally observed, on river red gums in other catchments in the region over recent decades.

The 2019 fire and other buffel-fuelled fires in Tjoritja are causing long-lasting impacts on the structural composition of river red gums within the park and the habitat they provide. The significance of this impact is especially apparent when the age of the trees that were destroyed at Ormiston Creek and, consequently, their previous (pre-invasion) resilience to multiple fires is considered. River red gums are estimated to take well over 100 years to grow to large size; therefore, the size structure of trees in the central Australian riparian woodlands will shift markedly downwards under repeated severe wildfires. The loss of large river red gums will substantially reduce available habitat for the many species that rely on large canopies for foraging and shelter. Even if younger and resprouting river red gums persist, the number and variety of hollows, critical to the reproduction of multiple wildlife species, is expected to become progressively more limited because smaller trees typically have few, small hollows if any (Westerhuis et al. 2019).

Although the importance of large hollow-bearing trees for fauna is globally recognised (Lindenmayer and Laurance 2016), the use of hollows by wildlife in central Australia has been less-well researched compared to many other regions, with targeted investigation limited to a few species (Princess Parrot, Polytelis alexandrae (Pavey et al. 2014); Nankeen Kestrel, Falco cenchroides (Aumann 2001); Owlet Nightjar, Aegotheles cristatus (Doucette et al. 2011)). Community-level studies indicate the value of river red gum woodlands more generally in supporting a suite of locally occurring nectivorous and insectivorous canopy foraging birds (Reid 2015; Westerhuis et al. 2020a). The abundance of large hollowbearing trees has been identified as an important predictor of bird assemblages in arid riparian woodlands (Pavey and Nano 2009) and is also correlated with increased levels of bat activity, especially in dry and hot conditions (Westerhuis et al. 2020b). Ten of the 12 locally occurring insectivorous bat species require trees for roosting and breeding. Although further research is required to better understand the impact on individual species, a suite of fauna are expected to be adversely impacted by the loss of large trees under repeated buffelfuelled fire, with long-term effects on regional diversity and ecosystem function.

\section{Changing fire regimes in invaded Australian arid ecosystems}

The extent to which the Tjoritja fire spread through the creek lines (e.g. see Fig. 6) represents a departure from 

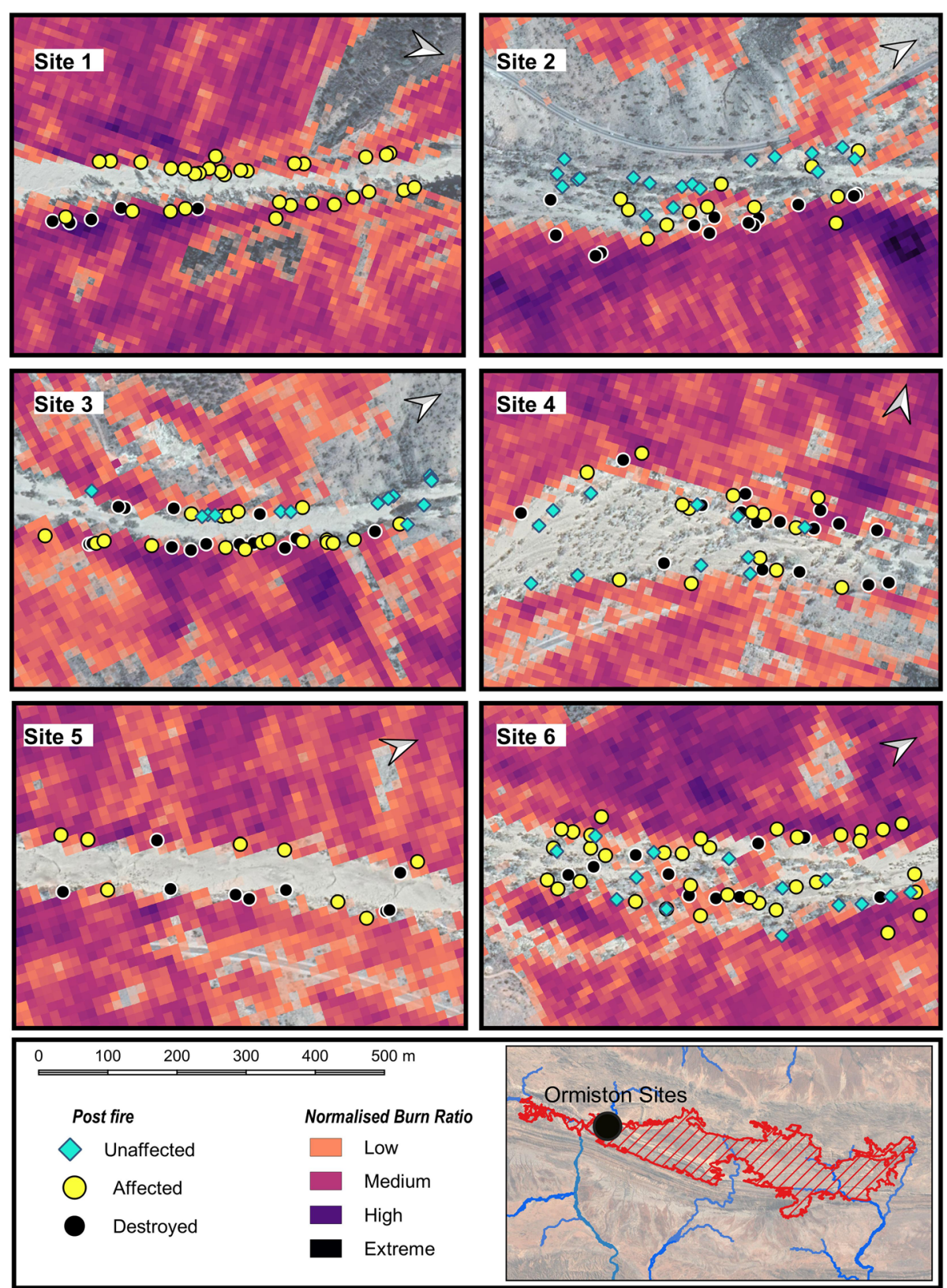

Fig. 5 Fire impact to trees at six sites along Ormiston Creek relative to $\Delta$ NBR calculated from Sentinel 2 imagery. Data were categorised according to equal intervals (low $=51-137$, medium $=138-225$, high $=226-312$, extreme $=313-400$ ) with darker colours indicating higher severity fire. Values below 50 were not displayed as examination of unburnt areas across the entire Sentinel image indicated this was the threhold above which change due to fire (as opposed to variation not related to fire) was observed. Inset shows entire fire scar relative to the study sites

historical fire patterns which were more likely to be confined to native spinifex communities, except following high rainfall periods. This novel pattern of spread enabled the 2019 fire to stay alight for many days and cover an extensive area. The government report on the fire states that 'buffel grass has played a significant role in the extent and severity of this wildfire. This grassy fuel helped transfer the fire across the park via the many creeks and rivers that it infests.' (Day 2020, p5). This is illustrated, for example, during the final days of the event ( 23 and 24 January) when the wildfire spread from spinifex hills to the east of Ormiston Creek into the creek-line (our study area) and then from the southeast to the north-west along the creek and through the adjacent hills (Day 2020). Meanwhile, the fire spread into the Finke River and Davenport Creek (that joins 


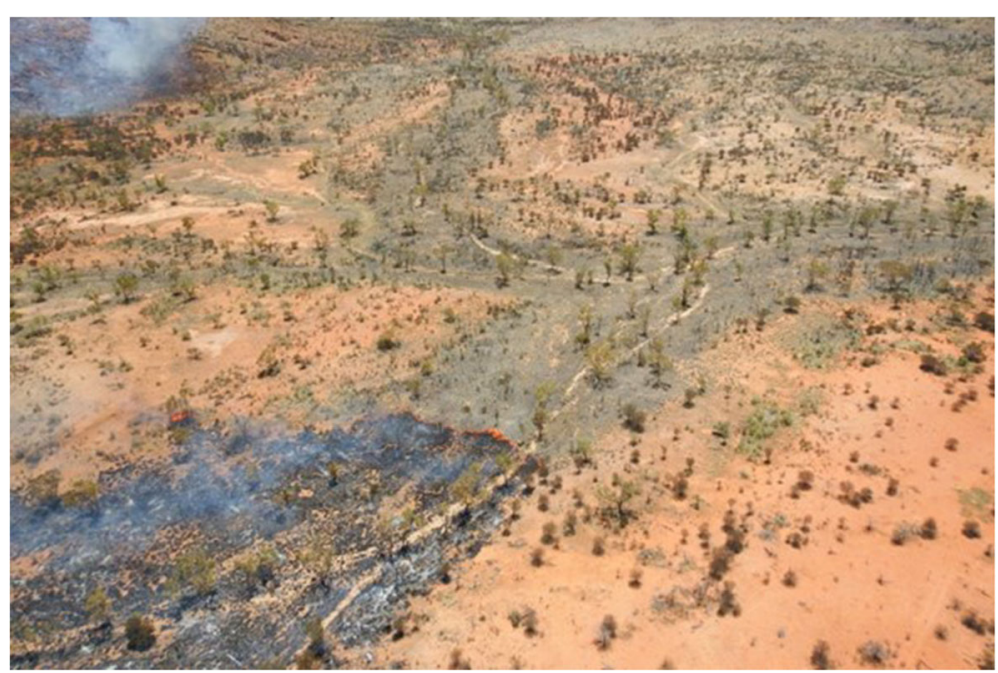

Fig. 6 Fire burning along floodplains on either side of a creek line during the 2019 Tjoritja fire (photo, Grant Allan). Dense areas of buffel grass appear grey. At this location adjacent areas lacked sufficient fuel to sustain fire spread. Trees along the drainage line are river red gums and shrubs in adjacent areas are mixed Acacias

Ormiston Creek at the head of the Finke) (Fig. 7). At Davenport Creek alone, more than $40 \mathrm{~km}$ of riparian vegetation burnt.

Prior to buffel grass invasion, spinifex was the most flammable vegetation community in arid Australia. Spinifex grasses are highly flammable, but produce discontinuous fuels, especially during the first few years following fire. Fire return times are typically between 5 and 20 years depending on region and rainfall (Edwards et al.
2008; Verhoeven et al. 2020) and coexisting overstorey plants are adapted to relatively frequent fire (MarsdenSmedley et al. 2012). Consequently, in Tjoritja and elsewhere across the inland, contemporary management to prevent large-scale wildfire has focussed predominantly on prescribed burning of spinifex communities to create a mosaic of different fire ages, an approach designed, in part, to replicate traditional burning practices of Australian Indigenous people.

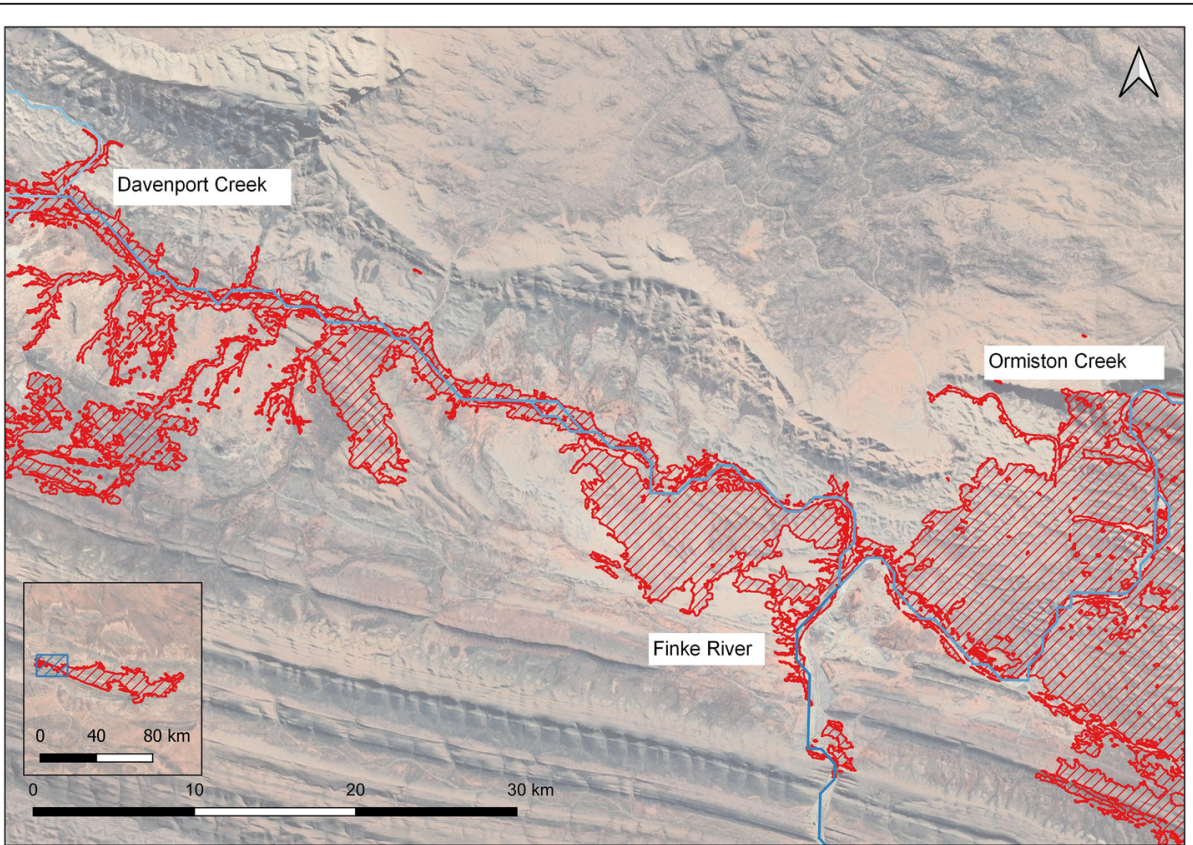

Fig. 7 Fire scars derived from Sentinel-2 imagery, at Ormiston Creek and in association with river and creek lines to the west during the final days of the fire event. Inset shows entire fire scar relative to the Ormiston Creek area 
In contrast, riparian woodlands have not, until recently, been targeted for fuel-reduction burning. Indeed, prior to invasion by introduced grasses, the biomass produced by native grasses of the lowlands was insufficient to support intense or widespread fire except following infrequent periods of prolonged high rainfall (Duguid et al. 2008; Edwards et al. 2008). Even following high summer rainfall, when the growth of native grass is promoted, the impact of native grass-fueled fire on trees is substantially reduced compared with areas where buffel grass dominates (Miller et al. 2010; Schlesinger et al. 2013). The long-lived overstorey species of the rivers and floodplains are not, consequently, well adapted to the severe fires that can now occur in buffel-invaded areas multiple times within a decade (Schlesinger et al. 2013; Read et al. 2020). Buffel grass is now recognised as one of the main wildfire risks for central Australia (Day 2020) and fuel-reduction burning or alternative management (e.g. mowing) of invaded areas has become increasingly necessary to protect infrastructure. It is recognised that burning of grass-invaded river red gum and other open woodland communities is not desirable from an ecosystem management perspective because of the damage caused to long-lived trees (Day 2020), but there are currently few viable alternatives.

Even considering the increasing regularity of buffelfuelled fires, both prescribed and unplanned, over the past two to three decades, the scale and timing of the 2019 Tjoritja wildfire was unprecedented. We propose this fire marks a significant point in a transition away from rare but relatively predictable, rainfall dependent large wildfires that were formerly typical of central Australia. Previously, large fires occurred in the warm season following two or more consecutive years of higher-than-average rainfall (Edwards et al. 2008; Marsden-Smedley et al. 2012; Verhoeven et al. 2020). But the Tjoritja wildfire was not preceded by high antecedent rainfall. The rapid re-accumulation of fuel loads in regions where buffel grass has heavily invaded, with much less rainfall, and the persistence of buffel fuels in the landscape, even during long-dry periods means large fires can now happen at almost any time. This is especially so as extreme weather that promotes fire and hinders containment efforts becomes more commonplace due to continuing anthopogenic climate change (Abatzoglou and Kolden 2011).

More frequent extreme weather patterns, including heat waves and extended droughts, have been predicted for arid Australia (Watterson et al. 2015), and this is supported by recent climate observations (Bureau of Meteorology 2021). Indeed, the Tjoritja wildfire occurred toward the end of a record heat wave in January 2019 which, combined with high wind speeds experienced during the two-week event, produced significant challenges for fire containment and undoubtably contributed to the extent of damage caused to large trees. Fuel continuity within spinifex communities was relatively low (too low to support control burning in the preceding cool season (Day 2020) but the record high temperatures in the preceding weeks would have reduced the moisture content of spinifex to extremely low levels which, under windy conditions, can enable the spread of fire even through such relatively 'young' spinifex (Burrows et al. 2018). Coupled with the spread of fire through the creeklines, where the continuous fine fuels produced by buffel grass promote fire spread even when temperatures and windspeeds are low (Schlesinger et al. 2013), these extreme conditions set the scene for an extraordinary event. We predict, however, that similar interactions between novel and native fuels and severe fire weather will promote more large and unpredictable fires of a comparable nature in the extensive areas now dominated by buffel grass across the Australian arid zone. Such fires, especially when combined with repeated more localised fires, will cause significant further decline of the large trees remaining in invaded areas throughout Tjoritja and in other invaded ecosystems across arid Australia within the next decade.

\section{Management implications}

Invasive grasses, including buffel grass, are usually extremely fire tolerant and regrow quickly after fire (Marshall et al. 2012; Pyšek et al. 2012; Rossiter et al. 2003; Setterfield et al. 2010) such that benefits of fuel-reduction burning in invaded ecosystems are brief. Furthermore, adverse impacts on trees from buffel-fuelled fire occur even in cool, still weather (Schlesinger et al. 2013; Day 2020). This makes fuelreduction burning in areas where biodiversity conservation is a primary objective problematic, except at very small scales at which individual trees can be protected. In our region, prescribed fire in native spinifex communities is effective at preventing the spread of wildfire through the wider landscape and, especially when adjacent to invaded areas, may reduce the risk of fire in buffel-grass dominated woodland communities. For example, the western side of Ormiston creek at site 2, which remained unburnt, had low fuel loads in January 2019 due to recent prescribed burning undertaken to protect infrastructure in the rocky hills west of the road (Grant Allan, pers. com; Fig. 4). This was likely a factor in preventing the fire in the creekline from jumping to the western bank, resulting in many trees at this site remaining unaffected. Additional resources that enable conservation managers to extend burning programmes in these fire-tolerant 
communities would be beneficial. However, alternative, effective methods to manage fire within invaded areas are also urgently required to reduce the risk of these areas acting as conduits for the spread of large wildfires, and to prevent further loss of keystone arid zone trees.

Pathogen or insect mediated biocontrol offers the best long-term prospect for landscape-scale management of buffel grass and associated fuel loads but because of the risks to buffel-dominated grazing lands, there has not been sufficient widespread socio-political support to enable exploration of this option. This may be changing, however, with increasing recognition of the level of threat buffel poses to ecosystems, biodiversity and associated social and cultural values, especially those of Aboriginal people who are the traditional custodians and majority of residents of semi-arid Australia (Read et al. 2020). Fire risk associated with buffel grass is greatest in un-grazed areas-conservation reserves and Aboriginal lands-and in the short to medium term, the management of fire in these areas is necessarily reliant on local-scale interventions. Integration of multiple management tools is required. Targeted application of herbicides and manual and mechanical removal are preferable to burning, especially where the persistence of large trees is already threatened, but more limited in the scale at which they can be implemented. Ideally, the outcome of management should be the restoration of areas of native vegetation, rather than simply the reduction of biomass in the short term. Although this requires greater effort initially, the level of maintenance long term will be reduced, and the resulting natural green breaks (Hulvey et al. 2017; Porensky et al. 2018) can provide multiple additional, measurable benefits for wildlife (Schlesinger et al. 2020). In Australia, and elsewhere where ecosystems have evolved without heavy grazing by large herbivores, the use of livestock grazing as a conservation tool is controversial, even (or especially) at sites that were previously heavily grazedlike Tjoritja. But a small number of reserves in eastern Australia are using grazing to minimise the impact of buffel-fuelled fires on fire sensitive vegetation communities; Meltzer (2015) and Lebbink et al. (2021) provide a comprehensive assessment of the practical challenges, benefits and risks. The consensus from these studies and a broader analysis by Lunt et al. (2007) is that grazing should only be used when there are no other effective options and that the costs to biodiversity and ecosystem integrity of reintroducing livestock into reserves are likely to outweigh benefits in many circumstances, especially in less productive dryland areas.
Managing fire to maintain biodiversity values in buffel grass-invaded areas is certain to remain a major challenge over the coming decades. To meet this challenge, it is crucial that conservation managers are adequately resourced to apply a range of management tools, assess the outcomes, and adapt their management accordingly.

\begin{abstract}
Acknowledgements
We gratefully acknowledge the environmental science and management students who helped collect the pre-fire field data during CDU's 2018 Desert Field Ecology field programme. We thank Grant Allan for information about the fire, permission to use the image in Fig. 6, and comments on an early draft of the manuscript. We also thank Marg Friedel, Izak Smit and an anonymous reviewer for comments on the manuscript.
\end{abstract}

\section{Authors' contributions}

CAS and ELW contributed equally to the conception of the work, interpretation of the data and drafting the manuscript. ELW led the data collection, remote-sensing and analyses. CAS led the revision of the manuscript. All authors read and approved the final manuscript.

\section{Authors' information}

CAS is a wildlife ecologist and senior lecturer at Charles Darwin University specialising in conservation ecology in desert environments and especially the impacts of introduced species on wildlife.

ELW is a post-graduate student at Charles Darwin University studying the ecology of arid riparian woodlands and importance for wildlife.

Funding

The research was funded by Charles Darwin University

\section{Availability of data and materials}

The datasets used and/or analysed during the current study are available from the corresponding author on reasonable request.

\section{Declarations}

Ethics approval and consent to participate

Not applicable

\section{Consent for publication}

Not applicable

\section{Competing interests}

The authors declare that they have no competing interests.

Received: 5 May 2021 Accepted: 21 September 2021

Published online: 06 November 2021

\section{References}

Abatzoglou, J.T., and C.A. Kolden. 2011. Climate change in Western US deserts: potential for increased wildfire and invasive annual grasses. Rangeland Ecology \& Management 64 (5): 471-478. https://doi.org/10.2111/REM-D-0900151.1 .

Abella, S.R., L.P. Chiquoine, and D.M. Backer. 2012. Ecological characteristics of sites invaded by buffelgrass (Pennisetum ciliare). Invasive Plant Science and Management 5 (4): 443-453. https://doi.org/10.1614/IPSM-D-12-00012.1.

Aumann, T. 2001. The structure of raptor assemblages in riparian environments in the south-west of the Northern Territory, Australia. Emu 101 (4): 293-304. https://doi.org/10.1071/MU00072.

Bureau of Meteorology. 2021. Climate Data Online. Available at: http://bom.gov.a u. Accessed 12 Oct 2021.

Burrows, N., M. Gill, and J. Sharples. 2018. Development and validation of a model for predicting fire behaviour in spinifex grasslands of arid Australia. International Journal of Wildland Fire 27 (4): 271-279. https://doi.org/10.1071/ WF17155.

Clarke, P.J., P.K. Latz, and D.E. Albrecht. 2005. Long-term changes in semi-arid vegetation: Invasion of an exotic perennial grass has larger effects than 
rainfall variability. Journal of Vegetation Science 16 (2): 237-248. https://doi. org/10.1111/j.1654-1103.2005.tb02361.x.

Clews, L. 2016. Observations on roost use by the yellow-bellied sheathtail-bat (Saccolaimus flaviventris) in northern New South Wales, Australia. Australian Mammalogy 39: 95.

Congedo, L. 2016. Semi-automatic classification plugin documentation. Release 4 $(0.1): 29$

D'Antonio, C.M., and P.M. Vitousek. 1992. Biological invasions by exotic grasses, the grass/fire cycle, and global change. Annual Review of Ecology and Systematics 23 (1): 63-87. https://doi.org/10.1146/annurev.es.23.110192.000431.

Day, C. 2020. Tjoritja West MacDonnell National Park, Report on the January 2019 Bushfire. Department of Tourism Sport and Culture, Northern Territory Government https://naturaldisaster.royalcommission.gov.au/system/files/202 0-07/TCS.500.001.0103.pdf. Accessed 2 Jan 2021.

Dean, W.R.J., S.J. Milton, and F. Jeltsch. 1999. Large trees, fertile islands, and birds in arid savanna. Journal of Arid Environments 41 (1): 61-78. https://doi.org/1 0.1006/jare.1998.0455.

Dickman, C.R. 1991. Use of trees by ground-dwelling mammals: implications for management. In Conservation of Australia's forest fauna, ed. D. Lunney. Mosman: Royal Zoological Society of New South Wales.

Doucette, L.I., R.M. Brigham, C.R. Pavey, and F. Geiser. 2011. Roost type influences torpor use by Australian owlet-nightjars. Naturwissenschaften 98 (10): $845-$ 858. https://doi.org/10.1007/s00114-011-0835-7.

Duguid, A., C. Brock, and K. Gabrys. 2008. A review of the fire management on central Australian conservation reserves: towards best practise. In Desert Fire: fire and regional land management in the arid landscapes of Australia, ed. G.P. Edwards and G.E. Allan. Alice Springs: Desert Knowledge Cooperative Research Centre.

Edwards, G.P., G.E. Allan, C. Brock, A. Duguid, K. Gabrys, and P. Vaarzon-Morel. 2008. Fire and its management in central Australia. The Rangeland Journal 30 (1): 109-121. https://doi.org/10.1071/RJ07037.

Fensham, R.J., B. Laffineur, and T. Collingwood. 2019. Eucalyptus camaldulensis. The IUCN Red List of Threatened Species 2019.

Friedel, M.H., G. Allan, and A. Duguid. 2014. Do we know enough about vegetation dynamics to manage fire regimes in central Australia? Ecological Management \& Restoration 15 (2): 128-132. https://doi.org/10.1111/emr.12104.

Gibbons, P., C. McElhinny, and D.B. Lindenmayer. 2010. What strategies are effective for perpetuating structures provided by old trees in harvested forests? A case study on trees with hollows in south-eastern Australia. Forest Ecology and Management 260 (6): 975-982. https://doi.org/10.1016/j.foreco.2 010.06.016.

Godfree, R., J. Firn, S. Johnson, N. Knerr, J. Stol, and V. Doerr. 2017. Why nonnative grasses pose a critical emerging threat to biodiversity conservation, habitat connectivity and agricultural production in multifunctional rural landscapes. Landscape Ecology 32 (6): 1219-1242. https://doi.org/10.1007/s1 0980-017-0516-9.

Goldingay, R.L. 2009. Characteristics of tree hollows used by Australian birds and bats. Wildlife Research 36 (5): 394-409. https://doi.org/10.1071/WR08172.

Goldingay, R.L. 2011. Characteristics of tree hollows used by Australian arboreal and scansorial mammals. Australian Journal of Zoology 59 (5): 277-294. https://doi.org/10.1071/ZO11081.

Grice, A.C. 2006. The impacts of invasive plant species on the biodiversity of Australian rangelands. The Rangeland Journal 28 (1): 27-35. https://doi.org/1 0.1071/RJ06014.

Haslem, A., S. Avitabile, R. Taylor, L. Kelly, S. Watson, D. Nimmo, S. Kenny, K. Callister, L. Spence-Bailey, A. Bennett, and M. Clarke. 2012. Time-since-fire and inter-fire interval influence hollow availability for fauna in a fire-prone system. Biological Conservation 152: 212-221. https:/doi.org/10.1016/j.biocon.2012.04.007.

Haworth, K., and G.R. McPherson. 1995. Effects of Quercus emoryi trees on precipitation distribution and microclimate in a semi-arid savanna. Journal of Arid Environments 31 (2): 153-170. https://doi.org/10.1006/jare.1995.0057.

Hulvey, K.B., E.A. Leger, L.M. Porensky, L.M. Roche, K.E. Veblen, A. Fund, J. Shaw, and E.S. Gornish. 2017. Restoration islands: a tool for efficiently restoring dryland ecosystems? Restoration Ecology 25: S124eS134.

Law, B., K.J. Park, and M.J. Lacki. 2016. Insectivorous bats and silviculture: balancing timber production and bat conservation. In Bats in the Anthropocene: Conservation of Bats in a Changing World, ed. C.C. Voigt and T. Kingston. Cham: Springer International Publishing.

Lebbink, G., M.J. Dwyer, and R.J. Fensham. 2021. Managed livestock grazing for conservation outcomes in a Queensland fragmented landscape. Ecological Management and Restoration 22 (1): 5-9. https://doi.org/10.1111/emr.12460.
Lindenmayer, D.B., and W.F. Laurance. 2016. The ecology, distribution, conservation and management of large old trees. Biological Reviews 92 (3): 1434-1458. https://doi.org/10.1111/brv.12290

Lindenmayer, D.B., W.F. Lawrence, and J.F. Franklin. 2012. Global decline in large old trees. Science 338 (6112): 1305-1306. https://doi.org/10.1126/science.1231 070 .

Lumsden, L.F., A.F. Bennett, and J.E. Silins. 2002a. Location of roosts of the lesser long-eared bat Nyctophilus geoffroyi and Gould's wattled bat Chalinolobus gouldii in a fragmented landscape in south-eastern Australia. Biological Conservation 106 (2): 237-249. https://doi.org/10.1016/50006-3207(01)00250-6.

Lumsden, L.F., A.F. Bennett, and J.E. Silins. 2002b. Selection of roost sites by the lesser long-eared bat (Nyctophilus geoffroyi) and Gould's wattled bat (Chalinolobus gouldii) in south-eastern Australia. Journal of Zoology 257 (2): 207-218. https://doi.org/10.1017/\$095283690200081X.

Lunt, I.D., D.J. Eldridge, J.W. Morgan, and G.B. Witt. 2007. A framework to predict the effects of livestock grazing and grazing exclusion on conservation values in natural ecosystems in Australia. Australian Journal of Botany 55 (4): 401415. https://doi.org/10.1071/BT06178.

Lutes, D.C., R.E. Keane, J.F. Caratti, C.H. Key, N.C. Benson, S. Sutherland, and Gangi, LJGTRR-G-FC, CO: US Department of Agriculture, Forest Service, Rocky Mountain Research Station. 1 CD. 2006. FIREMON: Fire effects monitoring and inventory system. Vol. 164.

Lynch, T. 2020. North Australia \& Rangelands Fire Information (NAFI) Map Services. https://github.com/nafi-org/nafi-ggis.

Majer, J.D., H.F. Recher, A.B. Wellington, J.C. Woinarski, and A.L. Yen. 1997. Chapter 12 Invertebrates of eucalypt formations. In Eucalypt ecology: individuals to ecosystems, ed. J.E. Williams and J. Woinarski. Cambridge: Cambridge University Press.

Marris, E. 2016. Blazes threaten iconic trees: as Tasmanian climate warms, bushfires are encroaching on forest ecosystems that date back more than 180 million years. Nature 530: 137+.

Marsden-Smedley, J.B., D. Albrecht, G.E. Allan, C. Brock, A. Duguid, M.H. Friedel, A. M. Gill, K.J. King, J. Morse, B. Ostendorf, and D. Turner. 2012. Vegetation-fire interactions in central arid Australia: towards a conceptual framework. NintiOne https://www.nintione.com.au/?p=4763. Accessed 2 Jan 2021.

Marshall, V.M., M.M. Lewis, and B. Ostendorf. 2012. Buffel grass (Cenchrus ciliaris) as an invader and threat to biodiversity in arid environments: a review. Journal of Arid Environments 78: 1-12. https://doi.org/10.1016/j.jaridenv.2 011.11.005.

McDonald, C.J., and G.R. McPherson. 2011. Fire behavior characteristics of buffelgrass-fueled fires and native plant community composition in invaded patches. Journal of Arid Environments 75 (11): 1147-1154. https://doi.org/10.1 016/j.jaridenv.2011.04.024.

McDonald, C.J., and G.R. McPherson. 2013. Creating hotter fires in the Sonoran Desert: buffelgrass produces copious fuels and high fire temperatures. Fire Ecology 9 (2): 26-39. https://doi.org/10.4996/fireecology.0902026.

McElhinny, C., P. Gibbons, C. Brack, and J. Bauhus. 2006. Fauna-habitat relaionships: a basis for identifying key stand structural attributes in temperate Australian eucalypt forests and woodlands. Pacific Conservation Biology 12 (2): 89-110. https://doi.org/10.1071/PC060089.

Meltzer, R.I. 2015. When is stock grazing and appropriate 'tool' for reducing Cenchrus cilliaris (buffel grass) on conservation reserves? Proceedings of the Royal Society of Queensland 120: 53-68.

Miller, G., M. Friedel, P. Adam, and V. Chewings. 2010. Ecological impacts of buffel grass (Cenchrus ciliaris L.) invasion in central Australia - does field evidence support a fire-invasion feedback? The Rangeland Journal 32: 353-365.

Nolan, R.H., M.M. Boer, L. Collins, V. Resco de Dios, H. Clarke, M. Jenkins, B. Kenny, and R.A. Bradstock. 2020. Causes and consequences of eastern Australia's 2019-20 season of mega-fires. Global Change Biology 26 (3): 1039-1041. https://doi.org/10.1111/gcb.14987.

Parnaby, H., D. Lunney, and M. Fleming. 2011. Four issues influencing the management of hollow-using bats of the Pilliga forests of inland New South Wales. In The Biology and Conservation of Australasian Bats, ed. B. Law, P. Eby, D. Lunney, and L. Lumsden. Mosman: Royal Zoological Society of New South Wales. https://doi.org/10.7882/FS.2011.041.

Pavey, C.R., and C.E.M. Nano. 2009. Bird assemblages of arid Australia: Vegetation patterns have a greater effect than disturbance and resource pulses. Journal of Arid Environments 73 (6): 634-642. https://doi.org/10.1016/j.jaridenv.2009. 01.010.

Pavey, C.R., C.E.M. Nano, J.R. Cole, P.J. McDonald, P. Nunn, A. Silcocks, and R. H. Clarke. 2014. The breeding and foraging ecology and abundance of 
the Princess Parrot (Polytelis alexandrae) during a population irruption. Emu-Austral Ornithology 114 (2): 106-115. https://doi.org/10.1071/MU13 050.

Porensky, L.M., B.L. Perryman, M.A. Williamson, M.D. Madsen, and E.A. Leger. 2018 Combining active restoration and targeted grazing to establish nativeplants and reduce fuel loads in invaded ecosystems. Ecology and Evolution 8 (24): 12533e12546. https://doi.org/10.1002/ece3.4642.

Pyšek, P., V. Jarošík, P.E. Hulme, J. Pergl, M. Hejda, U. Schaffner, and M. Vilà. 2012. A global assessment of invasive plant impacts on resident species, communities and ecosystems: the interaction of impact measures, invading species' traits and environment. Global Change Biology 18 (5): 1725-1737. https://doi.org/10.1111/j.1365-2486.2011.02636.x.

Read, J.L., J. Firn, A.C. Grice, R. Murphy, E. Ryan-Colton, and C.A. Schlesinger. 2020. Ranking buffel: Comparative risk and mitigation costs of key environmental and socio-cultural threats in central Australia. Ecology and Evolution 2020;10: 12745-12763. https://doi.org/10.1002/ece3.6724.

Reid, J. 2015. Avian diversity in arid Australia: patterns in species richness and composition across varied assemblages and environments. Doctor of Philosophy thesis, Australian National University.

Rhodes, M., and G. Wardell-Johnson. 2006. Roost tree characteristics determine use by the white-striped freetail bat (Tadarida australis, Chiroptera: Molossidae) in suburban subtropical Brisbane, Australia'. Austral Ecology 31 (2): 228-239. https://doi.org/10.1111/j.1442-9993.2006.01587.x.

Rodríguez-Rodríguez, L., E. Stafford, A. Williams, B. Wright, C. Kribs, and K. RíosSoto. 2017. A stage structured model of the impact of buffelgrass on saguaro cacti and their nurse trees, in

Rossiter, N.A., S.A. Setterfield, M.M. Douglas, and L.B. Hutley. 2003. Testing the grass-fire cycle: alien grass invasion in the tropical savannas of northern Australia. Diversity and Distributions 9 (3): 169-176. https://doi.org/10.1046/j.14 72-4642.2003.00020.x.

Schlesinger, C.A., S. White, and S. Muldoon. 2013. Spatial pattern and severity of fire in areas with and without buffel grass (Cenchrus ciliaris) and effects on native vegetation in central Australia. Austral Ecology 38 (7): 831-840. https:// doi.org/10.1111/aec. 12039

Schlesinger, C.A., M. Kaestli, K.A. Christian, and S. Muldoon. 2020. Response of reptiles to weed-control and native plant restoration in an arid, grassinvaded landscape. Global Ecology and Conservation 24: e01325. https://doi. org/10.1016/j.gecco.2020.e01325

Setterfield, S.A., N.A. Rossiter-Rachor, L.B. Hutley, M.M. Douglas, and R.J. Williams. 2010. Biodiversity research: turning up the heat: the impacts of Andropogon gayanus (gamba grass) invasion on fire behaviour in northern Australian savannas. Diversity and Distributions 16 (5): 854-861. https://doi.org/10.1111/ j.1472-4642.2010.00688.X.

van Klinken, R.D., and M.H. Friedel. 2017. Unassisted invasions: understanding and responding to Australia's high-impact environmental grass weeds. Australian Journal of Botany 65 (8): 678-690. https://doi.org/10.1071/BT1 7152.

Verhoeven, E.M., B.R. Murray, C.R. Dickman, G.M. Wardle, and A.C. Greenville. 2020. Fire and rain are one: extreme rainfall events predict wildfire extent in an arid grassland. International Journal of Wildland Fire 29 (8): 702-711. https:// doi.org/10.1071/WF19087.

Watterson, I., D. Abbs, J. Bhend, F. Chiew, J. Church, M. Ekström, D. Kirono, A. Lenton, C. Lucas, K. McInnes, A. Moise, D. Monselesen, F. Mpelasoka, L. Webb, and P. Whetton. 2015. Rangelands cluster report, climate change in Australia projections for Australia's natural resource management regions.

Westerhuis, E.L., C.A. Schlesinger, C.E.M. Nano, S.R. Morton, and K.A. Christian. 2019. Characteristics of hollows and hollow-bearing trees in semi-arid river red gum woodland and potential limitations for hollow-dependent wildlife. Austral Ecology 44 (6): 995-1004. https://doi.org/10.1111/aec.12765.

Westerhuis, E.L., C.E.M. Nano, S.R. Morton, K.A. Christian, and C.A. Schlesinger. 2020b. Stability and predictability of bird assemblages in an arid riparian woodland during contrasting periods of resource availability. Austral Ecology 45 (8) 1067-1079. https://doi.org/10.1111/aec.12933.

Westerhuis, E.L., S. Morton, K.A. Christian, and C.A. Schlesinger. 2020a. Temporal and spatial activity of insectivorous bats in arid riparian woodland. Pacific Conservation Biology 27 (2): 155-169. https://doi.org/10.1071/PC19051.

Whelan, C.J., and G.G. Maina. 2005. Effects of season, understorey vegetation density, habitat edge and tree diameter on patch-use by bark-foraging birds. Functional Ecology 19 (3): 529-536. https://doi.org/10.1111/j.1365-2435.2005. 00996.x.

\section{Publisher's Note}

Springer Nature remains neutral with regard to jurisdictional claims in published maps and institutional affiliations.

\section{Submit your manuscript to a SpringerOpen ${ }^{\circ}$ journal and benefit from:}

- Convenient online submission

- Rigorous peer review

- Open access: articles freely available online

- High visibility within the field

- Retaining the copyright to your article

Submit your next manuscript at $\boldsymbol{\nabla}$ springeropen.com 